\title{
Analysis of the World Scientific Production on the Topic of Industry 4.0 From 1990 to 2020
}

Marina Teixeira de Souza ${ }^{1}$, University of São Paulo, São Carlos, São Paulo, Brazil.

Fernando César Almada Santos², University of São Paulo, São Carlos, São Paulo, Brazil.

\section{RESUMO}

Objetivo - O objetivo deste artigo foi realizar uma análise da produção científica na temática de Indústria 4.0.

Referencial teórico - O trabalho apresenta uma revisão literária acerca do conceito, evolução e características da Indústria 4.0. Desenho/metodologia/abordagem - A metodologia proposta para este trabalho baseia-se na pesquisa bibliográfica e na aplicação de procedimentos da bibliometria.

Resultados - Foram encontrados 850 artigos até 2020. As publicações envolveram 2625 autores, de 75 países, 1084 instituições e 201 diferentes periódicos. Destaca-se que 88,3\% dos artigos foram publicados nos últimos três anos. Os países que mais se destacaram foram China e Itália e o periódico mais prolífico foi o Applied Sciences Basel, com 59 artigos. O artigo mais citado recebeu 343 citações e a maior produção por autor foi de 9 artigos. A temática teve ascensão significativa nos últimos anos com estudos empíricos e teóricos.

Implicações de pesquisa, práticas e sociais - Por se tratar de uma temática de exponencial interesse de acadêmicos, pesquisadores e gestores e por impactar diretamente modelos de negócios e estratégias organizacionais, o estudo teve como implicação apresentar de forma ordenada a evolução, tendências e desdobramentos da Indústria 4.0 no período de 1990 até 2020.

Originalidade/valor - A originalidade do estudo advém da lacuna identificada e que corresponde à necessidade de um estudo bibliométrico que apresentasse de maneira ordenada os principais países, anos de publicações, autores mais citados e que mais publicam, periódicos e palavras-chave recorrentes, além de identificar desdobramentos e tendências nessa temática.

Palavras-chave - Indústria 4.0. Quarta Revolução Industrial. Tendências.

\section{ABSTRACT}

Objective - This study aims to analyze the scientific production on the topic of Industry 4.0.

Theoretical framework - The work presented a literary review about the concept, how Industry 4.0. has developed and its characteristics.

Design/methodology/approach - The methodology proposed for this work is based on bibliographic research and the application of bibliometric procedures.

Findings - Eight hundred and fifty articles were found up to 2020. The publications involved 2,625 authors, from 75 countries, 1,084 institutions and 201 different journals. Highlighting that $88.3 \%$ of the articles were published in the last three years. The countries that stood out the most were China and Italy, and the most prolific journal was Applied Sciences Basel, with 59 articles. The most cited article received 343 citations and the largest production per author was nine articles. The topic has risen significantly in recent years with empirical and theoretical studies.

Research, Practical \& Social implications - The topic is of exponential interest for academics, researchers and managers and for directly impacting business models and organizational strategies, the study involved presenting the development and trends, in an orderly manner, of Industry 4.0 in the period from 1990 to 2020.

Originality/value - The originality of the study comes from the gap identified, which corresponds to the need for a bibliometric study that presented the main countries, years of publications, most cited and most published authors, periodicals and recurring keywords, in addition to identifying developments and trends in this topic.

Keywords - Industry 4.0. Fourth Industrial Revolution. Trends.

1.Universidade de São Paulo, Escola de Engenharia de São Carlos. Av. Trabalhador São-carlense, 400 - Departamento de Engenharia de Produção, Centro, 13566-590 - Sao Carlos, SP - Brasil - Caixa-postal: 359, ts.marina@usp.br; https://orcid.org/0000-0003-0030-9094. 2. almada@ @c.usp.br; https://orcid.org/0000-0002-9317-088X.

SOUZA, M. T.; SANTOS, F.C.A. Analysis of the World Scientific Production on the Topic of Industry 4.0 From 1990 to 2020. GEPROS. Gestão da Produção, Operações e Sistemas, v.16, nº 2, p. 153 - 167, 2021.

DOI: http://dx.doi.org/10.15675/gepros.v16i2.2783 


\section{INTRODUCTION}

The use of technology in the organizational environment revolutionized practices, business models and generated efficiency gains from the strategic allocation of human and material resources with the objective of generating profit and continuous optimization of processes (MAASZ; DARWISH, 2018).

Industry 4.0 has gained considerable attention among researchers and academics from around the world (LIAO; DESCHAMPS et al., 2017) because it is a fully connected and automated organizational system, in which decisions are made based on real-time information a fully integrated and linked set of equipment and people. Thus, there is a certain urgency on the part of companies to understand aspects of Industry 4.0 in order to remain competitive (KASAPOGLU, 2018).

The concept of Industry 4.0 was introduced at the Hannover Fair in 2011 and officially announced in 2013 as a German strategy to revolutionize the manufacturing sector (XU; XU et al., 2018). With the arrival of Industry 4.0, business processes using digital integration and intelligent engineering contributed greatly towards futuristic technology (MUHURI; SHUKLA et al., 2019).

Industry 4.0 represents the evolution of the Industrial Revolutions that have occurred. The first occurred between the 18th and 19th centuries and was represented by the introduction of mechanical manufacturing systems using water and steam energy. The Second Industrial Revolution dates from the end of the 19th century and is based on mass production and electricity. Subsequently, in the 20th century, the Third Industrial Revolution was based on the use of Information Technology (IT) in manufacturing production systems (XU; XU et al., 2018).

The Fourth Industrial Revolution, on the other hand, is related to the integration of the entire industrial ecosystem promoting fully interconnected solutions and is also linked to the rapid transformations in the design, production, implementation, operation and service of manufacturing systems and their products and components (OBERER; ERKOLLAR, 2018, XU; XU et al., 2018). To get the most out of the technologies and advantages provided by Industry 4.0, organizations need to invest in resources such as: data and connectivity, analysis and intelligence, conversion to the physical world and human-machine interaction. In 
addition, this investment is considered vital for companies that seek to keep up with emerging trends in production (MEDIC; ANISIC et al., 2019).

New possibilities can be made possible by Industry 4.0, whose components are: Big Data; simulation of production systems; Internet of Things (IoT); Cyberphysical Systems; Cloud computing; Virtual reality; Cybersecurity; Collaborative robots; Machine-to-machine communication. Recognizing the importance of all these components - which are discussed in a timely manner in this article -, there is no doubt the need for companies to pay attention and give due attention to the movements of the Fourth Industrial Revolution, since it directly impacts business models, organizational strategies and has potential for great opportunities for companies (MOEUF; PELLERIN et al., 2017).

The evident relevance of the theme and in relation to the evolution, trends and developments of Industry 4.0, the identified gap - based on the research carried out in the Web of Science database so far - is that there is a need to carry out a bibliometric study that presents in an orderly manner the main countries, years of publications, most cited and most published authors, periodicals and recurring keywords, in addition to identifying developments and trends in this theme.

Thus, the objective of this article is to carry out an analysis of international scientific production in the theme of Industry 4.0. Therefore, the article is organized as follows: Section 2 presents the theoretical framework on Industry 4.0; Section 3 presents the methodology used in the study; Section 4 presents the results and, finally, the final considerations and perspectives are presented in Section 5.

\section{THEORETICAL FOUNDATION}

The driving forces behind the evolution of production systems are the demands of people throughout history and the growing understanding of companies of the need to generate value for consumers. Variables such as service time, product or service quality, price, variety and volume are points of extreme attention on the part of organizations. The First Industrial Revolution, or also Industry 1.0, focused on the transition from feudal society to industrial society and marked by steam engines. The Second Industrial Revolution or Industry 2.0 represents a notable advance in the productive capacity of companies and electricity is a key factor. The Third Industrial Revolution or Industry 3.0 is marked by the 
incorporation of technology in terms of information technology, electronics, communication and robotics (YIN; STECKE et al., 2018).

The Fourth Industrial Revolution or Industry 4.0 is the combination of manufacturing operations systems and communication and information technologies. As a result, from the market point of view, customers are offered increasingly technological solutions. From the perspective of the company's internal environment, shorter machine programming times, high levels of productivity and significant reduction in operating costs are achieved. In addition, companies are enabled with flexible production, large-scale, real-time data analysis and improvements in decision making at the strategic, tactical and operational levels (DALENOGARE; BENITEZ et al., 2018).

There are inherent characteristics of Industry 4.0: horizontal integration, vertical integration and engineering support. The first, horizontal integration, refers to the computerized integration of all the company's activities - from customer orders, production to transportation and logistics. The second, vertical integration is related to the integration of all organizational levels of the company - operational, tactical and strategic levels. And the third characteristic is the engineering support that is linked to the goods produced - from the research, development and production of the product (UNGERMAN; DEDKOVA et al., 2018).

The main components of Industry 4.0 are presented in Table 1.

Table 1 - Components of Industry 4.0

\begin{tabular}{|c|l|}
\hline COMPONENTS & \multicolumn{1}{c|}{ CHARACTERISTICS } \\
\hline Big Data & $\begin{array}{l}\text { A company's data set and enables greater ability to make better decisions, } \\
\text { generating value for the business. It is an essential tool in organizational } \\
\text { relationships since it allows for increased productivity, reduced costs and } \\
\text { more effective decision-making. }\end{array}$ \\
\hline $\begin{array}{c}\text { Simulation of Production } \\
\text { Systems }\end{array}$ & $\begin{array}{l}\text { Possibility to analyze the performance of a product and the performance of the } \\
\text { production line. From this, it is possible to optimize the company's processes } \\
\text { and operations, in addition to the integration of the entire production system. }\end{array}$ \\
\hline Internet of Things (IoT) & $\begin{array}{l}\text { Interconnection of devices (such as computer, smartphone, tablet, etc.) in } \\
\text { order to gather and transmit data in real time in order to automate tasks } \\
\text { (example: mapping the consumer's buying habit; smart sensors that present in } \\
\text { real time the need for maintenance of equipment, interconnection of } \\
\text { production and logistics - intelligent manufacturing). }\end{array}$ \\
\hline Cyberphysical Systems & $\begin{array}{l}\text { Use of algorithms that enable the control and monitoring of systems and users } \\
\text { so that there is a systemic communication and gives responses in real time. }\end{array}$ \\
\hline Cloud Computing & $\begin{array}{l}\text { Provision and exchange of information between various systems and networks } \\
\text { and that can be accessed from anywhere, all the time and from any device. }\end{array}$ \\
\hline Virtual Reality & $\begin{array}{l}\text { Use of virtual reality technologies - such as smart glasses - to simulate } \\
\text { environments and / or objects that can be used to improve the design or make }\end{array}$ \\
\hline
\end{tabular}




\begin{tabular}{|c|l|}
\hline & a presentation of a prototype, for example. \\
\hline Cybersecurity & $\begin{array}{l}\text { Protection of networks of companies and users from cyber attacks, which can } \\
\text { take advantage of some vulnerability of the system and invade, manipulate or } \\
\text { even steal data and / or confidential information. }\end{array}$ \\
\hline Collaborative Robots & $\begin{array}{l}\text { Widely used in the automation of repetitive industrial processes, such as } \\
\text { packaging, inspections, loading / unloading, application and reading of bar } \\
\text { codes, application of labels, etc. }\end{array}$ \\
\hline $\begin{array}{c}\text { Machine-to-Machine } \\
\text { Communication }\end{array}$ & $\begin{array}{l}\text { Autonomous management of the machines and which allows for productivity } \\
\text { gains and mapping of bottlenecks in production processes. }\end{array}$ \\
\hline
\end{tabular}

Source: elaborated by the authors from Moeuf et al. (2017, p. 4).

However, organizations need to pay attention not only to characteristics and components, but also to workers, since they are directly affected by the new work format with regard to process automation, new procedures to be followed and combination of methods of work. These factors are what will enable the interoperability of the entire company system, enable transparency and the flow of information, allow the identification of gaps in production and enable increasingly decentralized and effective decision making in order to provide integration and operational efficiency (LONGO; NICOLETTI et al., 2017).

Employees begin to experience an even more complex scenario within organizations and need to present skills such as flexibility and adaptability, continuous learning, innovation and creativity, initiative and willingness, resilience, leadership, teamwork, communication, negotiation, systemic thinking, planning, problem solving, decision making and autonomy. In addition, it is essential that companies focus on the development of these skills in order to certify that workers are actually being incorporated into the context of Industry 4.0 together with all technological apparatus (SOUZA; SANTOS, 2020).

The implementation of Industry 4.0 can be made possible based on five factors: 1) Industrial Policy: based on the development of new business models; 2) Employment Policies: creation of jobs that demand qualified people; 3) Data Security: measures to protect confidential data of companies and users; 4) Medium-sized companies policy: actions aimed at fostering innovation in medium-sized companies; 5) Regulation: ways that present examples of application of Industry 4.0 to obtain competitive advantage in the market (MANA; CÉSAR et al., 2018).

It is a fact that Industry 4.0 promotes a paradigm shift in the management of small, medium and large companies and, to the same extent, offers increasing opportunities for improving planning, development, control and more effective decision making. The expectation is that Industry 4.0 will have the consequence of generating more jobs, new 
business models, improving the customer experience, developing workers' skills and increasing the competitiveness of companies (MARESOVA; SOUKAL et al., 2018).

Parallel to the changes and expectations, there are also challenges due to the growing interconnection of intra- and inter-company processes that are in the planning, introduction or maturation phase of Industry 4.0. The existing challenges are: Analysis and business strategies; Planning and implementation of the new model; Cooperation and network aiming at the creation of strategic alliances between the organization's partners; Management of new business models; People management in this new context; Change management and leadership. Certainly, these challenges will serve to guide and motivate academics, researchers and managers in this promising revolution that is Industry 4.0 (SCHNEIDER, 2018).

\section{METHODOLOGICAL PROCEDURES}

The methodology proposed for this work is based on bibliographic research and the application of bibliometric procedures, with the aim of presenting a bibliographic survey and quantifying the literature on Industry 4.0 in the period 1990 to 2020, however, articles were found published on from 2014 in the selected areas of interest. Figure 2 shows the steps proposed in the methodology and the main expected results in each phase.

Figure 1 - Graphical representation of the methodology phases

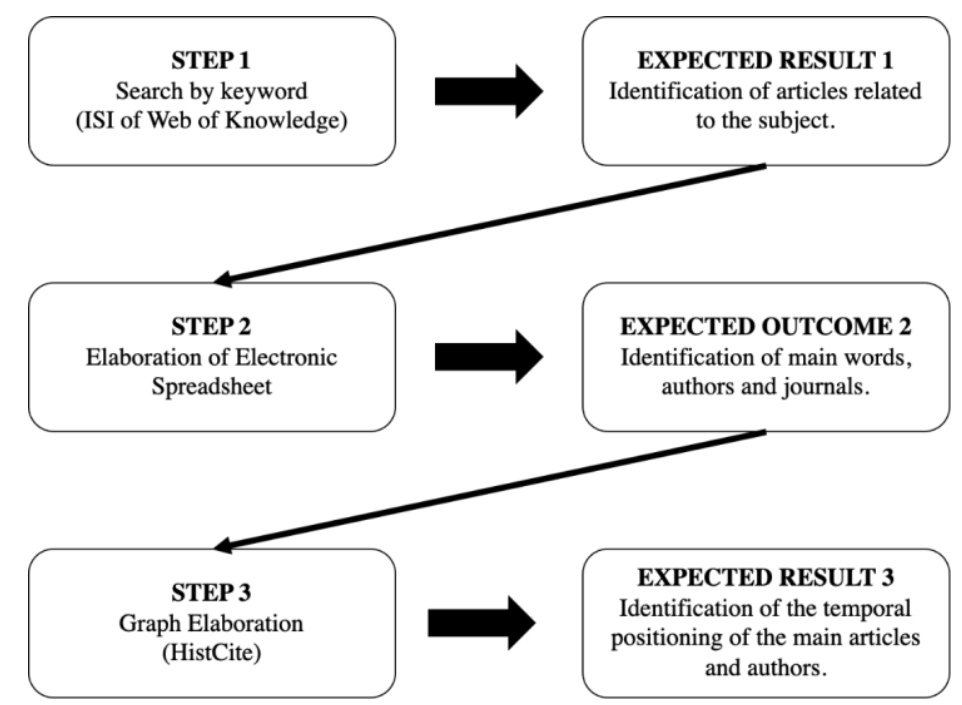

Source: Authors (2020). 
The database used to carry out the research was ISI Web of Science due to its relevance and scope, as it is used in 81 countries and has more than 21,000 indexed Journals since 1900 in more than 250 areas of the academy (THOMSON REUTERS, 2020). The initial sample of work was obtained through research in the referred database from the keywords "industr * 4.0" OR "4th industrial revolution" OR "fourth industrial revolution", using only the selection of articles, which resulted in 850 jobs - until September 23, 2020. The selected areas of interest were: Manufacturing Engineering / Manufacturing, Industrial Engineering, Management and Multidisciplinary Engineering. With the reading of the papers, those most selected for the area of interest were selected, restricting the sample to 850 articles. Figure 1 presents in detail the results obtained from the research.

Figure 2 - Search Results

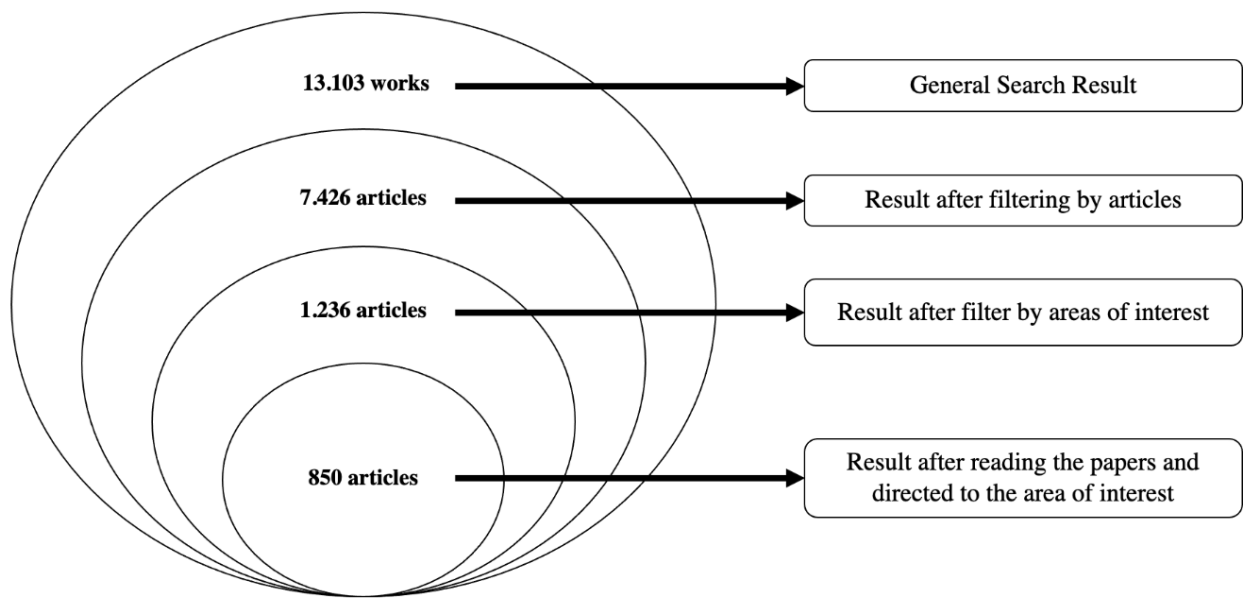

Source: Authors (2020).

From this selection, a database was created with the aid of VoS Viewer and the HistCite tool, software that facilitates the visualization of the results of searches carried out in ISI Web of Science through the structure of histories and relationships (GARFIELD, SOREN, et al., 2006). The data obtained relate the names of the articles, main words, articles by authors, journals in which the works were published and years of publication.

By analyzing these data, it was possible to detail aspects of the sample collected for the main countries, the most cited and most published authors, the journals with the highest number of publications and the most frequent words. These aspects corroborate to analyze the evolution, trends and developments of Industry 4.0. 


\section{RESULTS AND DISCUSSION}

This section is dedicated to presenting and discussing the main research findings obtained from the methodology used and presented in the previous section. In addition, it is a way of analyzing the evolution, trends and developments of Industry 4.0 with regard to academic production related to the theme.

From the data analyzed, it is noted that China is the country that has researched the most about Industry 4.0, representing $11.76 \%$ of publications. Italy has $10.35 \%$ of publications and is followed by the United States, with $9.88 \%$, and Germany with $9.29 \%$ of publications. Brazil is also on this list in seventh place with $6.35 \%$ of the publications. It can be seen that the publications have been concentrated in developed countries. However, there is a growing global interest in the theme of Industry 4.0.

Table 1 - Main Countries

Source: Authors (2020).

\begin{tabular}{cccc}
\hline n & COUNTRY & RECS $^{\mathbf{1}}$ & TGCS $^{\mathbf{2}}$ \\
\hline 1 & China & 100 & 1032 \\
2 & Italy & 86 & 636 \\
3 & USA & 83 & 1780 \\
4 & Germany & 79 & 1900 \\
5 & England & 69 & 756 \\
6 & Spain & 54 & 193 \\
7 & Brazil & 52 & 822 \\
8 & Poland & 48 & 295 \\
9 & France & 41 & 843 \\
10 & South Africa & 39 & 174 \\
\hline
\end{tabular}

Graph 1 shows the exponential growth in the last 6 years of publications and, consequently, interest in studies related to Industry 4.0. From the areas of interest considered in this research - Manufacturing Engineering / Manufacturing, Industrial Engineering, Management and Multidisciplinary Engineering -, it is noted that the first study is from 2014 and, since then, there has been a significant increase in publications in the selected areas. Related to this fact is the evident and legitimate interest on the part of companies to pay attention to the new processes, working methods and possibilities made possible by Industry 4.0 (KASAPOGLU, 2018; LONGO; NICOLETTI et al., 2017).

\footnotetext{
${ }^{1}$ RECS: número de registros encontrados na amostra (CLARIVATE, 2020).

2 TGCS: número de citações na Web of Science (CLARIVATE, 2020). 
Graph 1 - Main Years of Publications

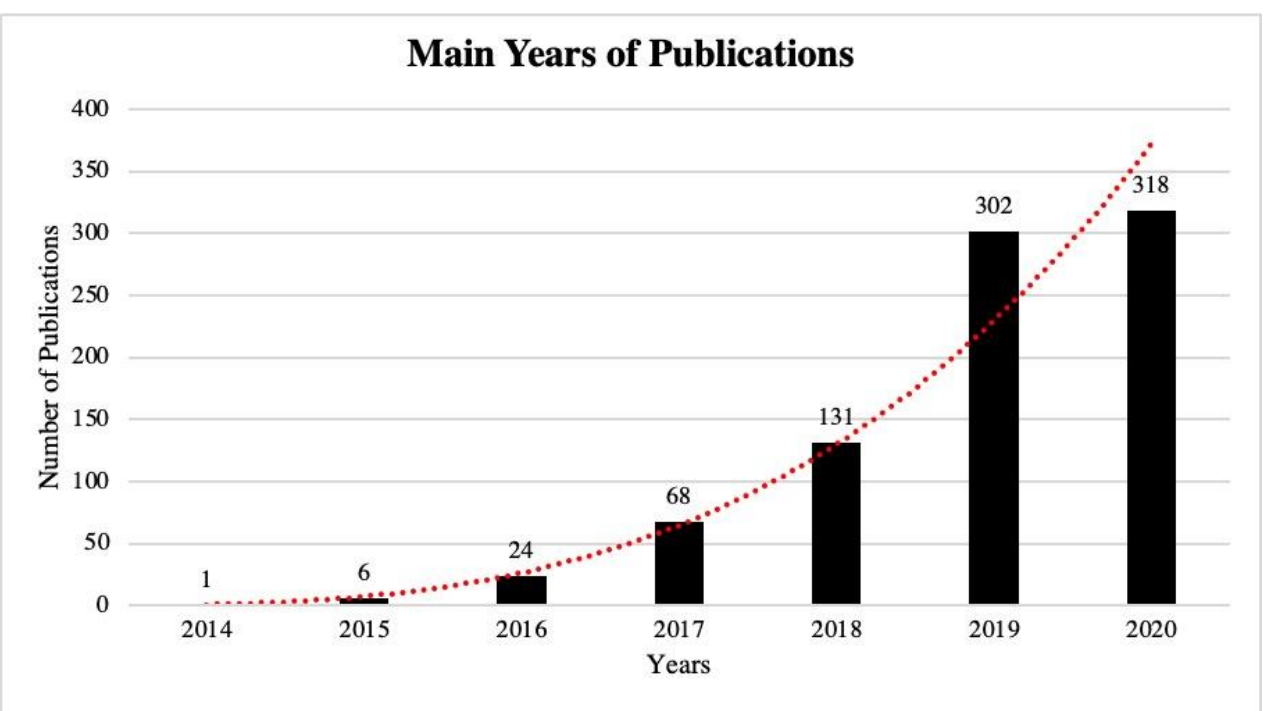

Source: Authors (2020).

Between the years 2018 and 2019 there was an increase of $130.53 \%$ in publications on this theme, a fact that reinforces the argument of exponential interest in the theme, the percentage of increase is even more significant when observed between the years 2014 and 2020, the study de Liao et al. (2017) supports the fact that Industry 4.0 has gained considerable attention among researchers and academics around the world. The year 2020 was not fully considered in the survey - as the survey took place until September 23, 2020 as mentioned in the Methodology section, however, the trend line continues to grow. Graph 1 complies with Bradford's Law, since it shows the historical evolution of the main years of publications (RODRIGUES; VIERA, 2016).

Table 2 corresponds to Lotka's Law, since it presents the 10 authors who most published and most cited within the areas of interest selected for this research (RODRIGUES; VIERA, 2016). As can be seen, there are no authors with significant numbers of publications on the topic, however, there are significant numbers with regard to the number of citations that these authors received.

Table 2 - Main Authors

\begin{tabular}{cccc}
\hline $\mathbf{N}$ & AUTHORS & RECS $^{\mathbf{3}}$ & TGCS $^{\mathbf{4}}$ \\
\hline 1 & Xu X & 9 & 218 \\
2 & Voigt KI & 7 & 212 \\
3 & Tortorella GL & 6 & 154 \\
4 & Chen Y & 5 & 1 \\
\hline
\end{tabular}

\footnotetext{
${ }^{3}$ RECS: number of records found in the sample (CLARIVATE, 2020).

${ }^{4}$ TGCS: number of citations on the Web of Science (CLARIVATE, 2020).
} 
Source: Authors (2020).

\begin{tabular}{cccc}
\hline 5 & Dolgui A & 5 & 366 \\
6 & Garza-Reyes J & 5 & 66 \\
7 & Kumar M & 5 & 2 \\
8 & Kumar S & 5 & 15 \\
9 & Lamouri S & 5 & 147 \\
10 & Li D & 5 & 130 \\
\hline
\end{tabular}

An interesting fact to note is that the authors were not cited in articles in the database used for this bibliometric research, however, they were cited in works from other areas of knowledge, not considered by this study.

In the analysis of results, 201 different journals were identified, however, despite the considerable number, three of these journals published about $17 \%$ of the works considered in this research. It is relevant to point out that the Science and Technology area is the one that most publishes on the subject. Table 3 presents the main journals about the research carried out and complies with the Bradford Law, as it shows the most prolific journals on the subject (RODRIGUES; VIERA, 2016).

Table 3 - Main Journals

\begin{tabular}{cccc}
\hline $\mathbf{n}$ & JOURNAL & RECS $^{\mathbf{5}}$ & TGCS $^{\mathbf{6}}$ \\
\hline 1 & Applied Sciences-Basel & 59 & 123 \\
2 & International Journal of Advanced Manufacturing Technology & 46 & 159 \\
3 & International Journal of Production Research & 43 & 1707 \\
4 & Ieee Transactions on Industrial Informatics & 34 & 679 \\
5 & Computers \& Industrial Engineering & 28 & 297 \\
6 & Journal of Manufacturing Technology Management & 21 & 209 \\
7 & Production Planning \& Control & 20 & 169 \\
8 & International Journal of Computer Integrated Manufacturing & 19 & 117 \\
9 & South African Journal of Industrial Engineering & 18 & 46 \\
10 & Systems Research and Behavioral Science & 17 & 24 \\
\hline
\end{tabular}

Source: Authors (2020).

From the 850 articles selected in this bibliometric research, the 10 main words that are recurrent in the works considered are: industry, manufacturing, based, industrial, smart, systems, production, digital, system, management. The words confirm the direction to the theme of this work.

Table 4 - Main Words

\begin{tabular}{cccc}
\hline $\mathbf{n}$ & WORDS & RECS & TGCS \\
\hline 1 & Industry & 356 & 4537 \\
2 & Manufacturing & 160 & 2500 \\
3 & Based & 99 & 650 \\
4 & Industrial & 93 & 1306 \\
5 & Smart & 79 & 856 \\
\hline
\end{tabular}

\footnotetext{
${ }^{5}$ RECS: number of records found in the sample (CLARIVATE, 2020).

${ }^{6}$ TGCS: number of citations on the Web of Science (CLARIVATE, 2020).
} 
Source: Authors (2020).

\begin{tabular}{cccc}
\hline 6 & Systems & 75 & 1020 \\
7 & Production & 74 & 780 \\
8 & Digital & 60 & 432 \\
9 & System & 59 & 245 \\
10 & Management & 55 & 533 \\
\hline
\end{tabular}

In addition, it is also possible to analyze the relationships between the words of the 850 articles selected by the research from a broader, systemic perspective that presents the developments of Industry 4.0, as shown in Figure 3. Figure 3 meets the Zipf Law, whereas it highlights the main approaches to the theme (RODRIGUES; VIERA, 2016).

Figure 3 - Unfolding between the main words

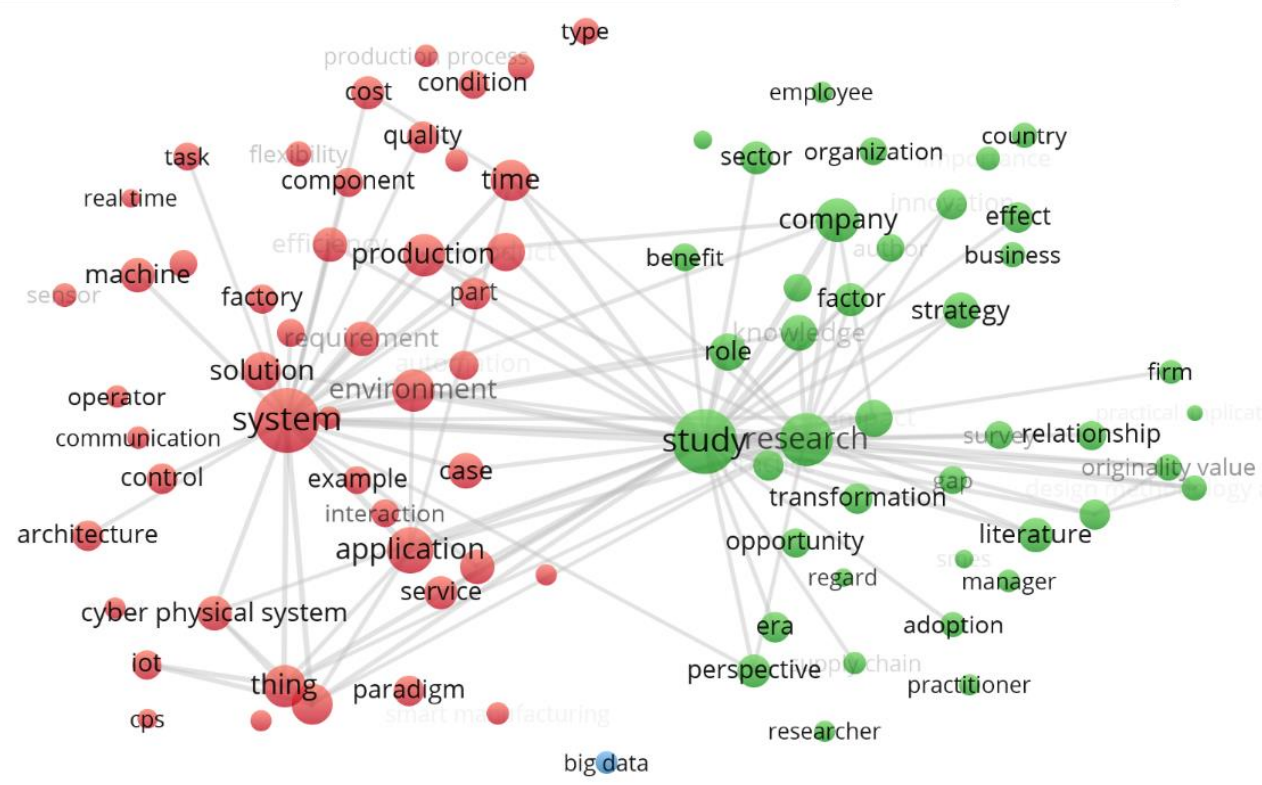

Source: Authors (2020).

From Figure 3, it is noted that the most evident words are system and study. This occurrence supports the fact that there is a growing number of studies being conducted on the theme of Industry 4.0 and that encompass the list of words associated with the corporate context, such as: employees, managers, factories, strategy, business, opportunities, applications, productions and quality - among all the others presented in Figure 3. Allied to these words are the challenges of Industry 4.0 pointed out by Schneider (2018) and that can be explored in future studies: business analysis and strategies; Planning and implementation of the new model; Cooperation and network aiming at the creation of strategic alliances between the organization's partners; Management of new business models; People management in this new context; Change management and leadership. 
It is relevant to analyze the tendencies of words about the theme of Industry 4.0 that serve as guidelines and present the words that can serve as a basis for future studies, as shown in Figure 4.

Figure 4 - Heat map of the main words

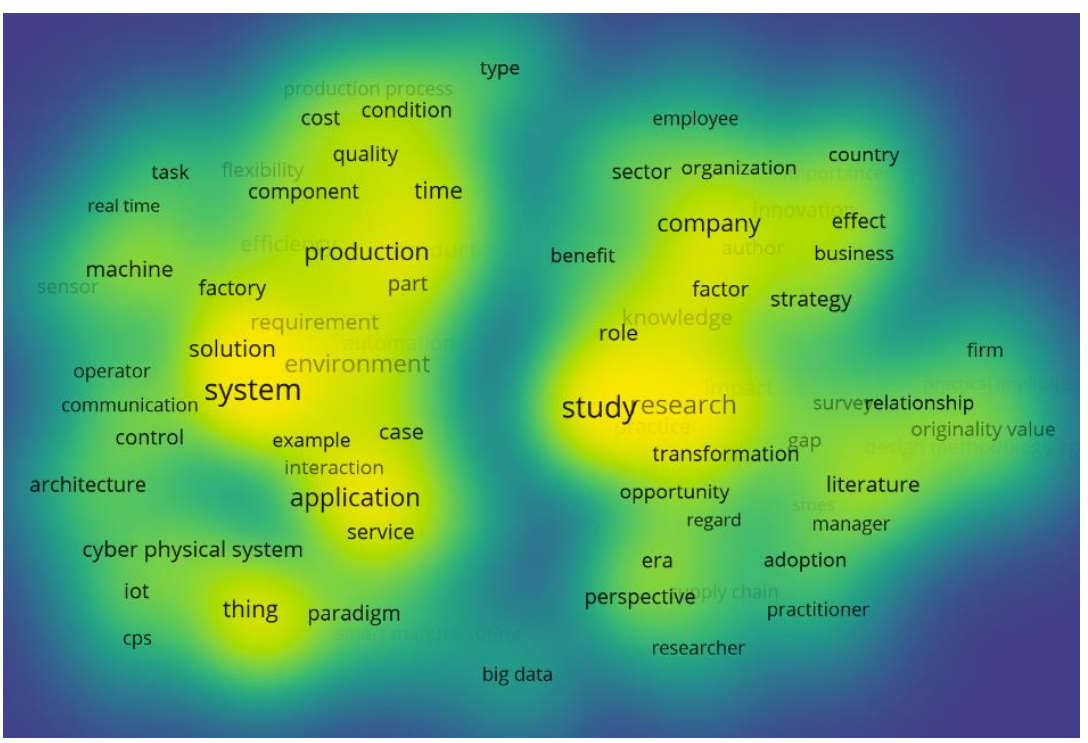

Source: Authors (2020).

The heat maps allow the following analysis: the red color represents a greater concentration of interest, the yellow color represents a growing and consolidating concentration and the green color indicates a trend of concentration of interest (SOUZA, 2018). Thus, it can be seen from Figure 4, that words close to system and study there is a growing and frequent concentration of studies, whereas words such as strategy, factory, operator, firm, country, employee, researcher, are trends of interest and it is up to organizations to follow these trends in order to remain competitive (MEDIC; ANISIC et al., 2019; OBERER; ERKOLLAR, 2018; XU; XU et al., 2018). However, there is no word that is highlighted by the color red, a fact that can be explained by the fact that studies on the theme of Industry 4.0 are still incipient.

\section{CONCLUSION}

It is considered that the objective of the study was achieved - to carry out an analysis of scientific production in the theme of Industry 4.0 - and, in a complementary way, developments and trends about the theme were identified. 
The results obtained from the bibliometric research showed that the main developments of the theme are associated with the corporate context and in the following variables: employees, managers, factories, strategy, business, opportunities, applications, productions and quality. This fact is important for the academic and managerial circles, since it enables new studies, perspectives and further research on the subject.

Regarding the trends of studies about Industry 4.0, it can be said that, based on the results obtained by this study, there is an increasing concentration of studies related to the production systems, operators, applications and opportunities of Industry 4.0. In addition, the area with the most studies is Science and Technology and the most prolific countries are China, Italy, the United States and Germany.

Therefore, there is an evident and exponential interest in aspects of Industry 4.0, however, there are still gaps to be explored regarding the variables of the corporate context. Thus, for future studies, it is suggested to deepen the variables presented in order to provide understanding to the academic and managerial environment of organizations that are in the planning and implementation phase of Industry 4.0.

\section{References}

CLARIVATE.

Available::

$<$ https://support.clarivate.com/ScientificandAcademicResearch/s/article/HistCite-

Glossary?language=en_US $>$. Acessed on 2th feb. 2020.

DALENOGARE, L. S., BENITEZ, G. B., AYALA, N. F., et al. "The expected contribution of Industry 4.0 technologies for industrial performance", International Journal of Production Economics, v. 204, n. July, p. 383-394, 2018. DOI: 10.1016/j.ijpe.2018.08.019. Available:: https://doi.org/10.1016/j.ijpe.2018.08.019.

GARFIELD, E., SOREN, P., WOLFGANG, S. "HistCite TM: A software tool for informetric analysis of citation linkage", Information - Wissenschaft und Praxis, v. 57, n. 8, p. 391400, 2006.

KASAPOGLU, Ö. "Leadership and Organization for the Companies in the Process of Industry 4.0 Transformation", International Journal of Organizational Leadership, v. 7, n. 3, p. 300-308, 2018. DOI: 10.33844/ijol.2018.60217. .

LIAO, Y., DESCHAMPS, F., LOURES, E. de F. R., et al. "Past, present and future of Industry 4.0 - a systematic literature review and research agenda proposal", International Journal of Production Research, v. 55, n. 12, p. 3609-3629, 2017. DOI: 10.1080/00207543.2017.1308576.

Available:

http://dx.doi.org/10.1080/00207543.2017.1308576. 
LONGO, F., NICOLETTI, L., PADOVANO, A. "Smart operators in industry 4.0: A humancentered approach to enhance operators' capabilities and competencies within the new smart factory context", Computers and Industrial Engineering, v. 113, p. 144-159, 2017. DOI: 10.1016/j.cie.2017.09.016. Available:: http://dx.doi.org/10.1016/j.cie.2017.09.016.

MAASZ, G. J., DARWISH, H. "Towards an initiative-based industry 4.0 maturity improvement process: Master drilling as a case study", South African Journal of Industrial Engineering, v. 29, n. 3, p. 92-107, 2018. DOI: 10.7166/29-3-2052. .

MANA, R., CÉSAR, F. I. G., MAKIYA, I. K., et al. "The concept of the industry 4.0 in a German multinational instrumentation and control company: a case study of a subsidiary in Brazil", Independent Journal of Management \& Production, v. 9, n. 3, p. 933, 2018. DOI: 10.14807/ijmp.v9i3.665. .

MARESOVA, P., SOUKAL, I., SVOBODOVA, L., et al. "Consequences of industry 4.0 in business and economics", Economies, v. 6, n. 3, p. 1-14, 2018. DOI: 10.3390/economies6030046. .

MEDIC, N., ANISIC, Z., LALIC, B., et al. "Hybrid fuzzy multi attribute decision making model for evaluation of advanced digital technologies in manufacturing: Industry 4.0 perspective", Advances in Production Engineering \& Management, v. 14, n. 4, p. 483493, 2019.

MOEUF, A., PELLERIN, R., LAMOURI, S., et al. "The industrial management of SMEs in the era of Industry 4 . 0", International Journal of Production Research, Ver p. 4, 9, 11 e 12, v. 7543, n. September, p. 0, 2017. DOI: 10.1080/00207543.2017.1372647. Available:: https://doi.org/10.1080/00207543.2017.1372647.

MUHURI, P. K., SHUKLA, A. K., ABRAHAM, A. "Industry 4.0: A bibliometric analysis and detailed overview", Engineering Applications of Artificial Intelligence, v. 78, n. December 2018, p. 218-235, 2019. DOI: 10.1016/j.engappai.2018.11.007. Available:: https://doi.org/10.1016/j.engappai.2018.11.007.

OBERER, B., ERKOLLAR, A. "Leadership 4.0: Digital Leaders in the Age of Industry 4.0", International Journal of Organizational Leadership, v. 7, n. 4, p. 404-412, 2018. DOI: 10.33844/ijol.2018.60332. .

RODRIGUES, C., VIERA, A. F. G. "Estudos bibliométricos sobre a produção científica da temática Tecnologias de Informação e Comunicação em bibliotecas", Revista de Ciência da Informação e Documentação, v. 7, n. 1, p. 167, 2016. DOI: 10.11606/issn.21782075.v7i1p167-180. .

SCHNEIDER, P. Managerial challenges of Industry 4.0: an empirically backed research agenda for a nascent field. [S.1.], Springer Berlin Heidelberg, 2018. v. 12. Available: https://doi.org/10.1007/s11846-018-0283-2.

SOUZA, M. T. de. Anúncios Orgânicos e Patrocinados: estudo sobre intenção de compra online e comportamento visual. 2018. 1-109 f. Universidade de São Paulo, Ribeirão Preto, 2018. DOI: 10.11606/D.96.2018.tde-28032018-153527. Available: https://www.teses.usp.br/teses/disponiveis/96/96132/tde-28032018-153527/pt-br.php.

SOUZA, M. T., SANTOS, F. C. A. "Competências Operacionais e Industria 4.0: Revisão Sistemática da Literatura", Future Studies Research Journal: Trends and Strategies, v. 12, n. 2, p. 264-288, 2020. DOI: 10.24023/futurejournal/2175-5825/2020.v12i2.499. . 
UNGERMAN, O., DEDKOVA, J., GURINOVA, K. "The Impact of Marketing Innovation on the Competitiveness of Enterprises in the Context of Industry 4.0", Journal of Competitiveness, v. 10, n. 2, p. 132-148, 2018. DOI: 10.7441/joc.2018.02.09. .

XU, L. Da, XU, E. L., LI, L. "Industry 4 . 0 : state of the art and future trends", v. 7543, 2018. DOI: 10.1080/00207543.2018.1444806. .

YIN, Y., STECKE, K. E., LI, D. "The evolution of production systems from Industry 2.0 through Industry 4.0", International Journal of Production Research, v. 56, n. 1-2, p. 848861, 2018. DOI: 10.1080/00207543.2017.1403664. Available: https://doi.org/10.1080/00207543.2017.1403664. 